\title{
Strengthening the Role of the Judicial Commission Through Innovative Strategies to Balance Independence and Impartiality with Judge Accountability
}

\author{
I Made Pria Dharsana \\ Faculty of Law, Warmadewa University, Denpasar, Bali, Indonesia \\ http://dx.doi.org/10.18415/ijmmu.v8i10.2997
}

\begin{abstract}
The role of the Judicial Commission is very important in the power of the judiciary because one of the forms of state administration in Indonesia is helping to implement an integrity system in the exercise of judicial authority. Besides that, it is also stated in Article 24B paragraph (1) of the Constitution that the Judicial Commission is independent in nature which has the authority to propose the appointment of Supreme Court justices and has other powers in the context of maintaining and upholding the honor, dignity, and behavior of judges. The enactment of Law Number 8 of 2011 is one form of strategy in strengthening checks and balances in judicial power. as for the research method used in this study is a normative legal research method. Furthermore, it is unfortunate that the external authority granted by Law Number 22 of 2004 and has been amended by Law Number 18 of 2011 concerning the Judicial Commission, is very limited, and the limited powers were later amputated by the decision of the Constitutional Court. This limited authority belongs to the enforcement of the Code of Ethics for the Code of Conduct for Judges (KEPPH). This authority is clearly not optimal and then becomes an obstacle for the Judicial Commission in designing innovative strategies in balancing judicial power through Independence, Impartiality and Accountability in the implementation of Judges containing fair decisions.
\end{abstract}

Keywords: Strengthening the Judicial Commission; Balancing Strategy of Independence; Impartiality; Accountability of Judges

\section{Introduction}

The provisions in Article 1 paragraph 3 of the 1945 Constitution that Indonesia is a state of law, which was adopted through the theory of the rule of law, rechtstaat or nomocracy, the essence of which is to mention that state administration is based on law and the basis for its implementation must be according to law. as described by Plato (Through Nomoi) was then continued again by his student named Aristotle. Aristotle himself has introduced the necessity of a constitution and the rule of law (recht souvereniteit) in a country. The State of Indonesia as a legal state cannot be separated from European law, namely Continental Europe, which before that time was colonized by the Dutch for approximately 360 years. The purpose of the rule of law itself is to protect human rights, the concept of rechtstaat which puts forward the principle of equality before the law, while the Republic of Indonesia puts forward the principle of wetmetigheid and the rule of law puts forward the principle of equality before the law, while the State of 
the Republic of Indonesia prioritizes the principle of harmony in the relationship between the government and the people. As for the elements of the rule of law, namely (Marbun, 1997):

1. Protection and Recognition of Human Rights

2. A state based on the trias politica theory;

3. The government is organized by law (wetmatigbestuur); and

4. The existence of a state administrative court tasked with handling cases of unlawful acts by the Government (onrechtmatigedaad).

The four elements are administrators in the capacity of the rule of law, in the development of dynamics they have improved, namely as follows (Ridwan, 2010):

1. A system of government based on people's sovereignty;

2. That the government carries out its duties and obligations must comply with laws and regulations;

3. There is a guarantee in the form of legal certainty for human rights (citizens);

4. structural division of power within the state;

5. supervision of judicial bodies (Rechterlijke controle) is free and independent so that judicial institutions are truly independent and not influenced by power;

6. the real role of community members and participate in supervising the implementation of policies implemented in the government;

7. An economic system that can guarantee an equitable distribution of resources and the prosperity of the Indonesian nation.

The close relationship between the administration of a country that has the capacity, especially in supervising judicial bodies, which is contained in point 5 of the explanation above, which of course aims to make the role of the judiciary in the rules of nobility and the enforcement of a good code of ethics in the situation on the ground. There is a conflict between the provisions of the 1945 Constitution and the 1949 RIS concerning Judicial power, more precisely in Article 24 paragraph 2 and Article 24A including Article 14 paragraph (1) in the regulation of the President's Clemency and Rehabilitation. Besides that, as Article 24 of the 1945 Constitution stipulates that the power of judges is exercised by a supreme court and the judiciary is under it, both general courts, religious courts, military courts and state administrative courts, while Article 24A regulates about:

1. The Supreme Court has the authority to adjudicate cassation, examine the legislation under the statutory regulations against the law;

2. Supreme Court Justices must have high integrity in carrying out their positions and must not be disgraceful, professional in their fields which is in the Legal Context in Indonesia;

3. Candidates for Supreme Court Justices must be proposed through the Judicial Commission to the DPR and obtain approval from the President;

4. Both the Chairperson and Deputy are directly elected by the Supreme Court Justices;

5. The composition of the position and membership is regulated by law.

The reflection of the role of the Judicial Commission in judicial power is clearly regulated in the Constitution in Article 24 A that the Judicial Commission will carry out the supervision system for judges as a state institution with the hope and purpose of THE JUDICIAL COMMISSION exercising the authority to supervise judges' behavior. The power of judges is independent and accountable in carrying out the duties mandated by the constitution and other related laws. This is where the important role of THE JUDICIAL COMMISSION in the constitutional system, as for: 
1. Weak monitoring since the independence era whose supervision is not intensive on power, in this case the monitoring system is on the Internal side and the lack of guarding against external disturbances;

2. this is due to the absence of a bridge between the government and the supremacist institutions, especially the judiciary;

3. The power of judges lacks efficiency and effectiveness;

4. Inconsistency of Decisions;

5. Regarding the recruitment of judges whose institutions are proposed to have the least influence of political interests.

The establishment of the Judicial Commission is of course so that Indonesia can achieve the goals of multidimensional reform in the life of the nation, of course, which are related to the various social, economic, political, cultural and legal aspects of Indonesia. so that later it is expected to bring a positive aura for the progress of the judicial power system later. Based on the description above, the authors want to examine how the application of judicial accountability to judges in the affirmation system carried out by the Judicial Commission in Indonesia, and how the role of the judicial commission through innovative strategies to balance independence and impartiality with judge accountability.

\section{Research Method}

The legal research used in making this scientific paper refers to normative law research that uses literature review materials, secondary data and doctrinal legal research, which aims to find a rule of law, legal principles and doctrines in order to answer legal issues that are currently being discussed. When faced through this concept, legal rules or norms will become benchmarks and guidelines for humans who are considered appropriate.

\section{Results and Discussion}

\subsection{The Existence of the Supreme Court in the Establishment of the Judicial Commission}

The formation of amendments to the 1945 Law which was suspected as the beginning of the birth of the Judicial Commission institution which at that time was a new institution with the hope of upholding honor and improving the dynamic behavior of judges whose function was still far from the word conducive Judiciary and guided by the context of justice, because it was full of intervention. of deviant judges. as the results of the amendments to the 1945 Constitution were then accommodated into Article $24 \mathrm{~B}$ and then finally enacted in Law Number 22 of 2004. long before Law Number 22 of 2004 was ratified there was a transfer of power from President Soeharto to President BJ Habibie. President BJ Habibie held governmental power in poor political, economic and legal conditions. To restore or reorganize political, economic and legal institutions in conditions such as during the reformation period is not easy. In the political field, President BJ Habibie opened the faucet for changes to the Political Law by giving everyone the opportunity to establish a political party, opening the taps for press freedom, freedom of expression, freedom of assembly was wide open, in the New Order regime it was severely restrained and restricted. Absorbing the aspirations of the community the implementation of Regional Autonomy (Subrata, 1998).

In managing the economic sector, the reform government opens and strengthens the creation of corporate legal entities through an online legal entity legalization system, so that it is fast, cheap and simple. Then Law No. 30/1999 on Arbitration and Dispute Settlement outside the Court was ratified. This is a demand from business actors because conventional courts or ordinary courts cannot resolve business disputes quickly, cheaply and in a fast time and most importantly business settlements in Indonesian courts cannot be trusted Indonesia is a state of law, not a state of power. As a state of law, it is determined the validity, usefulness and certainty of law to the community and as a fulfillment of the demands for reform

\footnotetext{
Strengthening the Role of the Judicial Commission Through Innovative Strategies to Balance Independence and Impartiality with Judge Accountability 330
} 
in the arrangement of the Indonesian state administration, the 1945 Constitution was amended, by including the Judicial Commission in Article 34B paragraph 1. The Judicial Commission has the authority to propose and propose candidates for Supreme Court Justices and other authorities to maintain, uphold the dignity, nobility and behavior of judges. The Judicial Commission is contained in the constitutional provisions in strengthening external supervision, considering that the internal supervision provided to the Supreme Court is not carried out optimally, resulting in reduced public trust in the judiciary. Supervision of violations of the code of ethics and behavior of judges is still weak. For this reason, external supervision is needed to be given to the Judicial Commission so that supervision in the implementation of judges in carrying out their duties that are free, independent and impartial does not violate the dignity and nobility of their positions as judges. The freedom granted by the law is carried out responsibly so that public trust in the judiciary is increasing. Increased trust in the Indonesian judiciary will increase the law and increase the confidence of the business world to invest in Indonesia (Subeki, 2008).

President Jokowi in his remarks at the 2019 Supreme Court annual report at the Jakarta Convention Center in early 2020; give high appreciation to the supervision carried out by the MA and THE JUDICIAL COMMISSION on the execution of the duties of judges. With an increase in public trust in the judiciary, public trust in the judiciary, trust in the law will increase. Thus, it can make people aware and obey the law. Awareness and obedience to the law will ease the task of judges in carrying out their duties. That the law does not merely have a repressive face. The level of misappropriation of funds that is included in one type of criminal act, namely corruption, has prompted the Supreme Court to submit an application for filling positions to the Judicial Commission. The existence of a political will policy in the Jokowi government focuses on preventive measures, especially in providing security guarantees for the smooth running of business and investment. Prevention of corruption. However, it is unfortunate that the number of corruption in Indonesia is still quite high. The influence of policies depends on how the government's policies themselves, but in addition to internal factors, it also affects by and how the capacity of the positions occupied by the judges at the Supreme Court can be carried out properly without any concerns about the practice corruption that is increasingly reluctant to bring good news.

As quoted in the problematic analysis of Hakim Ma's crisis by Rishan (2021), it seems very clear that the current conditions between the judicial commission and the Supreme Court are mismatches in the context of the gap between salaries and the needs of the realization of advertisers for the position of ad hoc judges in the Supreme Court. found in ad hoc judges. the existence of a criminal act of corruption (tipikor) makes the performance of the Supreme Court disrupted. As for the problem, the term of office for adoc judges has received serious attention from the formation of a law, which is based on the Supreme Court Law, the term of office of the Supreme Judge is determined based on the category of the maximum number of judges serving, which is 70 years and can be extended for 5 years. and may be appointed for one term. so that there is a need for an overhaul as decisions for justice based on the one and only divinity have a value. Strength that binds the disputing parties is considered to be disturbing at this time, far from being virtuous and full of awareness both in terms of truth and justice. Violations of the judge's code of ethics are often found. This injustice then raises judgments from the community towards judges who take a pessimistic attitude and doubt the majesty and sanctity of the position of a judge itself and ultimately degrade the trust of the community itself. This lack of awareness has become a barrier to the role of the Judicial Commission supervisor in implementing a very minimal internal control system towards implementing checks and balances in the judicial system that affects the judicial system in Indonesia.

\subsection{Judicial Accountability to Judges by the Role of the Judicial Commission in Indonesia}

A democratic transition from the New Order regime took place. not only until the economic crisis led to the reform process. the transfer of power then made the situation used as a golden transition moment. on the transition to democracy the institutional functions in the Government in revitalize. the strengthening occurs through the spirit of constitutionalism in the idea of dismantling the sacredness of the 1945 Constitution.

Strengthening the Role of the Judicial Commission Through Innovative Strategies to Balance Independence and Impartiality with Judge Accountability 331 
As a state of law, every provision of state administration and public life is based on law. In the implementation of community life, it is necessary to obey the law, both in the field of political, economic and social activities. In the New Order era, the faucet of the radial world was very scary and very closed. That the law is very sharp down for the poor and the poor do not get proper treatment as they should. Everyone is equal before the law, in practice it is felt far from it. the existence of an understanding of Independence in the principle of Independence in the context of the judiciary's power in examining, deciding or adjudicating cannot be intervened especially through supervision (Fajar ND, 2021).

The power possessed by the judiciary should not be reviewed in absolute terms without any exceptions, it is seen that the position is filled by a Naturalrecht Person who is capable of acting legally and fairly in analyzing legal issues as well as deciding cases in court. synergize with the understanding of power limitation so as not to create abuse of authority and create a circulation of power regardless of the characteristics of accountability itself. while accountability is useful for eliminating the risk of unlimited judges' independence which has the potential to cause behavioral and ethical deviations. Second, the experience of supervising judges in the old order only reached the professionalism of judges in deciding cases. does not involve the behavior of judges, the imposition of sanctions in the form of permanent dismissal with pension rights and permanent dismissal with respect, the Judicial Commission proposes it to the Honorary Council of Judges. Fourth, within the framework of checks and balances and limitation of power, the authority to impose sanctions in the form of dismissal of pension rights and permanent dismissal is not with respect to being a judicial commission with the Supreme Court Justices in the form of the Honorary Council of Judges as a forum for the self-defense of the Judges reported. Fifth, the Judicial Commission in the context of accountability must always prioritize the spirit of independence in law enforcement. In the statutory provisions, a judge exercises his authority freely, independently, and impartially or impartially, anyone from any party cannot intervene, threaten and influence a judge's decision. The freedom and impartiality of judges in deciding cases will be reflected in their decisions and the sense of justice felt by people seeking justice. However, the independence and impartiality of judges is absolute. Does this mean that there is a clean judiciary? In many cases and the weakness of supervision over the behavior of judges causes a lack of trust in the community in the judiciary. The judiciary is very closed and can become corrupt. There is no clarity on the timing of dispute resolution, gaps or disparities in dispute decisions by different judges on the same or similar cases or problems (Chotidjah, 2010).

The independence and impartiality held by judges in exercising their authority cannot be carried out without supervision so that judicial tyranny does not occur. The supervision given to the Supreme Court is apparently not enough to create a deterrent effect or impose sanctions on judges who have clearly violated the dignity of their positions and injure the public's sense of justice. The independence and impartiality of judges should also be supervised by a state institution, namely the Judicial Commission in order to fulfill the expectations of the people seeking justice.

The Judicial Commission's innovative strategy to balance independence and impartiality with judges' accountability One of the hopes and hopes of the community is to create a clean judiciary that can be realized easily and without obstacles. but it is very unfortunate as the supervisory function in the external authority granted by Law Number 22 of 2004 and has been amended by Law Number 18 of 2011 concerning the Judicial Commission, is very limited, and the limited powers were later amputated by the decision of the Constitutional Court. then this limited authority has the weakness of being unable to carry out the maximum enforcement of the Code of Ethics for the Code of Conduct for Judges (KEPPH). The number of reports submitted by the community to the Judicial Commission were then recommended but not followed up by the Supreme Court. The authority in supervising the implementation of KEPPH is very limited, the authority is given without any action. Recommendations issued by The Judicial Commission and the trial for violations of KEPPH are carried out in a closed manner and cannot be conveyed openly to the public so that THE JUDICIAL COMMISSION is impressed as a toothless tiger.

This is where the public does not understand the Judicial Commission's very narrow and limited authority. If so, what can The Judicial Commission do so that the supervision of KEPPH can be carried out 
effectively and on target, but there is no impression of interfering with the independence and impartiality of judges in making decisions. An innovative strategy that can be taken by the Judicial Commission is to take advantage of the provisions of Article 3 of Law 18 of 2011 which states that the Judicial Commission can form liaisons in the regions as needed. This idea is very strategic to be able to mobilize and involve the community in reporting to The Judicial Commission for violations of KEPPH by regional judges. The limited scope of supervision of the judiciary owned by The Judicial Commission can be overcome by establishing liaisons in the regions so that judges will feel bound and responsible to carry out their duties properly. This strategic and innovative idea must be a program that awakens the public so that judges in deciding cases are based on certainty and justice that grows in the community. As a state institution, one of the main tasks that must be carried out is to be able to respond and struggle to participate in creating public trust. With this awareness, the community will benefit from a clean judiciary. Such a judge's decision will be accounted for or assessed in an accountable manner. Judicial Accountability means that the judge must be able to explain what his considerations are so that a case is decided A or B and in deciding the judge not only obeys the law but also the code of ethics. This will be considered by The Judicial Commission in selecting and proposing candidates for Supreme Court Justices. Thus the strategic role of Judicial Commission in the midst of the limitations provided by the law can still be carried out strategically and innovatively in creating a clean judiciary. With a clean judiciary, the promise of reform can be paid off.

As the concept of the rule of law, Indonesia itself adopts the concept of an orderly state due to the existence of legal milestones that are upheld in accordance with the justice of its people. in the constitution there is a statement that confirms that the above-mentioned legal sovereignty is placed as well as the basis for people's sovereignty. the formation and administration of government which is regulated in a legal state, there is an instrument to protect and prosper the community in the aspect of government to the community as a whole. Likewise, in Article 24 paragraph 1 of the 1945 Constitution, namely the existence of an independent judicial power in the context of administering a clean and authoritative judiciary.

The role of judges should have a sense of justice through the corridors of mystical feelings felt by the community in examining a decision issue and the interests of all parties who have a relationship with the judiciary. Purwoto Gandasoebrata very firmly stated that as a former Chief Justice of the Supreme Court, the consequences of a rule of law when there is power must also be balanced with being able to uphold the authority of the law.

The editorial on one of the platforms of Indonesia's national daily contains the opinions of entrepreneurs who are worried that doing business in Indonesia is not a security issue but a legal certainty issue. Because the investment climate requires political stability, competitive economic opportunities, and legal certainty. none of that existed at the end of the New Order government. The economic recession in 1999 that hit ASEAN countries including Indonesia. The great pressure of the US Dollar against the rupiah exchange rate brought down the Indonesian economy which was built on an unsteady foundation. The collapse of the Indonesian economy led to large-scale popular demonstrations spearheaded by students, and led to the collapse of the New Order government, which was built through pseudo-political power. Political, economic instability and lack of legal certainty in Indonesia have caused many investors to leave Indonesia and shift their business to other countries. Social injustice is also felt by many regions and many crimes arise.

\section{Conclusion}

Strengthening the role of the Judicial Commission requires the formulation of innovative strategies in the form of implementing the Code of ethics and code of Conduct in the supervisory system of judges, as well as the principle of prudence in selecting a candidate for a judge who is truly qualified so as not to in the end violate the authority and ignore impartiality. of Accountability as well as to be able to balance Independence and Impartiality with Judges' Accountability towards making decisions based on justice for all parties in the concept of Equality Before the Law.

Strengthening the Role of the Judicial Commission Through Innovative Strategies to Balance Independence and Impartiality with Judge Accountability 333 


\section{References}

Chotidjah, N. (2010). Eksistensi Komisi Yudisial dalam Mewujudkan kekuasaan Kehakiman yang merdeka. Bandung, Fakultas Hukum Unisba.

Fajar ND, M. (2021). Dilema Kekauasaan Kehakiman. Harian Kompas, https://www.kompas.id/baca/opini/2021/07/19/dilema-kekuasaan-kehakiman/

Marbun, S.F. (1997). Peradilan Administrasi Negara dan Upaya Administratif di Indonesia. Yogyakarta, Liberty.

Ridwan, H.R. (2010). Hukum Administrasi Negara. Jakarta, Rajawali Press.

Rishan, I. (2021). Problem Krisis Hakim MA. Harian Kompas, https://www.kompas.id/baca/opini/2021/07/19/problema-krisis-hakim-ma/

Subekti, V.S. (2008). Menyusun Konstitusi Transisi: Pergulatan Kepentingan dan Pemikiran dalam Proses Perubahan UUD 1945. Jakarta, PT. RajaGrafindo Persada.

Subrata, G. (1998). Renungan Hukum. Jakarta, IKAHI.

\section{Copyrights}

Copyright for this article is retained by the author(s), with first publication rights granted to the journal.

This is an open-access article distributed under the terms and conditions of the Creative Commons Attribution license (http://creativecommons.org/licenses/by/4.0/). 